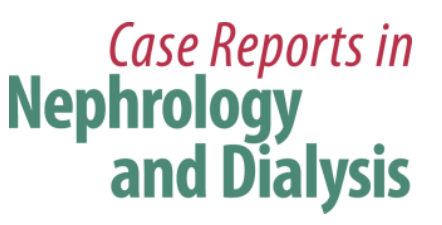

Case Rep Nephrol Dial 2016;6:76-82

DOI: $10.1159 / 000446019$

Publisnea onine: IVIay Z4, 2016

\title{
Phospholipase A2 Receptor-Positive Idiopathic Membranous Glomerulonephritis with Onset at 95 Years: Case Report
}

\author{
Keiichi Kubota $^{a}$ Junichi Hoshino ${ }^{a}$ Toshiharu Ueno ${ }^{a}$ Koki Mise $^{a}$ \\ Ryo Hazue $^{a} \quad$ Akinari Sekine $^{a} \quad$ Junko Yabuuchi ${ }^{a}$ Masayuki Yamanouchi ${ }^{a}$ \\ Tatsuya Suwabe $^{\mathrm{a}}$ Koichi Kikuchi $^{\mathrm{a}}$ Keiichi Sumida $^{\mathrm{a}}$ Noriko Hayami $^{\mathrm{a}}$ \\ Naoki Sawa ${ }^{a}$ Kenmei Takaichi ${ }^{a, c}$ Takeshi Fujiib Kenichi Ohashi ${ }^{b, d}$ \\ Shinichi Akiyama ${ }^{\mathrm{e}}$ Shoichi Maruyama ${ }^{\mathrm{e}}$ Yoshifumi Ubara ${ }^{\mathrm{a}, \mathrm{c}}$ \\ ${ }^{a}$ Nephrology Center and ${ }^{b}$ Department of Pathology, Toranomon Hospital, and \\ 'Okinaka Memorial Institute for Medical Research, Toranomon Hospital, Tokyo, \\ ${ }^{\mathrm{d}}$ Department of Pathology, Graduate School of Medicine, Yokohama City University, \\ Yokohama, and ${ }^{\mathrm{e} D i v i s i o n}$ of Nephrology, Department of Internal Medicine, Nagoya \\ University Graduate School of Medicine, Aichi, Japan
}

\section{Key Words}

Elderly nephropathy · Anti-phospholipase A2 receptor antibody · Idiopathic membranous glomerulonephritis

\begin{abstract}
A 95-year-old woman was admitted to our hospital for evaluation of bilateral lower-limb edema persisting for 3 months. Serum creatinine was $1.55 \mathrm{mg} / \mathrm{dl}$, and urinary protein excretion was $9.1 \mathrm{~g} /$ day. Renal biopsy revealed stage 1 membranous glomerulonephritis (MGN) with immunoglobulin G4-dominant staining. This patient did not have any underlying disease such as infection with hepatitis B or C virus or malignancy, and anti-phospholipase A2 receptor (PLA2R) antibody was detected in the serum. Accordingly, idiopathic MGN was diagnosed. Corticosteroid therapy was avoided, but hemodialysis was required to treat generalized edema. The patient is currently doing well. This is the oldest reported case of idiopathic MGN with positivity for anti-PLA2R antibody.




\section{Case Reports in \\ Nephrology \\ and Dialysis}

\begin{tabular}{l|l}
\hline Case Rep Nephrol Dial 2016;6:76-82 \\
\hline DOI: 10.1159/000446019 & $\begin{array}{l}\text { ○ 2016 The Author(s). Published by S. Karger AG, Basel } \\
\text { www.karger.com/cnd }\end{array}$ \\
\hline
\end{tabular}

Kubota et al.: Phospholipase A2 Receptor-Positive Idiopathic Membranous Glomerulonephritis with Onset at 95 Years: Case Report

\section{Introduction}

Membranous glomerulonephritis (MGN) is the most important cause of nephrotic syndrome in adults. Among patients $>60$ years old, secondary MGN is more common, especially due to underlying malignancy [1]. In 2009, the M-type phospholipase A2 receptor (PLA2R) was identified as the major podocyte antigen involved in idiopathic adult MGN, while antiPLA2R antibody is not detected in secondary MGN [2]. We encountered a 95-year-old Japanese woman who developed nephrotic-range proteinuria. Renal biopsy revealed stage 1 MGN with immunoglobulin (Ig)G4-dominant staining. This patient did not have any underlying disease that could cause secondary MGN, and anti-PLA2R antibody was detected in her serum, so idiopathic MGN was diagnosed. This is the oldest reported case of idiopathic MGN, and it is discussed with reference to the literature.

\section{Case Presentation}

In July 2014, a 95-year-old Japanese woman was admitted to our hospital with a 3month history of bilateral edema of the lower extremities. When she developed chronic diarrhea at 90 years of age (in 2009), laboratory tests revealed that serum creatinine (Cre) was $1.6 \mathrm{mg} / \mathrm{dl}$, albumin was $3.2 \mathrm{~g} / \mathrm{dl}$, and urinary protein excretion was $0.32 \mathrm{~g} /$ day.

She had no history of smoking, alcohol intake, or malignancy. On admission, she was 153 $\mathrm{cm}$ tall and weighed $56.4 \mathrm{~kg}$. Her blood pressure was $138 / 70 \mathrm{~mm}$ Hg. There were bilateral edema of the lower extremities.

Laboratory tests revealed a white blood cell count of $4,600 / \mu \mathrm{l}$, a red blood cell count of $3.71 \times 10^{6} / \mu \mathrm{l}$, hemoglobin of $11.7 \mathrm{~g} / \mathrm{dl}$, and platelet count of $21.3 \times 10^{4} / \mu \mathrm{l}$. In addition, total protein was $6.3 \mathrm{~g} / \mathrm{dl}$, albumin was $2.4 \mathrm{~g} / \mathrm{dl}$, serum urea nitrogen was $26 \mathrm{mg} / \mathrm{dl}$, serum Cre was $1.55 \mathrm{mg} / \mathrm{dl}$, C-reactive protein was $1.6 \mathrm{mg} / \mathrm{dl}$, and lactate dehydrogenase was $257 \mathrm{IU} / \mathrm{l}$ (normal: 119-229 IU/l). Immunological tests showed that antinuclear antibody, anti-doublestranded DNA antibody, and U1-nuclear ribonucleoprotein antibody were all negative. IgG was $1,340 \mathrm{mg} / \mathrm{dl}$, IgA was $427 \mathrm{~g} / \mathrm{dl}$, and IgM was $266 \mathrm{mg} / \mathrm{dl}$. The serum level of C3 was 123 $\mathrm{mg} / \mathrm{dl}$ (normal: >86 mg/dl), C4 was $19 \mathrm{mg} / \mathrm{dl}$ (normal: >18 mg/dl), and CH50 was $38 \mathrm{U} / \mathrm{ml}$ (normal: $>30 \mathrm{U} / \mathrm{ml}$ ). The patient was negative for hepatitis B virus antibody, hepatitis $\mathrm{C}$ virus antibody, and Treponema antigen. Urinary protein excretion was $9.1 \mathrm{~g} /$ day, and the sediment contained 5-10 erythrocytes per high-power field. Urinary Bence Jones protein was negative by immunofixation electrophoresis.

No findings suggestive of malignancy were revealed by imaging studies such as computed tomography and ultrasonography. The long axis of the kidney was calculated to be $9.0 \mathrm{~cm}$ bilaterally. Serum anti-PLA2R autoantibody was positive according to the method of Akiyama et al. [3]. Renal biopsy was done to evaluate the renal changes in this patient.

\section{Renal Biopsy}

Light microscopy of a renal biopsy specimen containing 36 glomeruli revealed global sclerosis in 22 of them (fig. 1a). The other 13 glomeruli showed mild mesangial matrix expansion (fig. 2a), but there was no definite spike formation, bubbling, or thickening of the glomerular basement membrane (GBM) (fig. 2b). In the tubulointerstitial region, atrophy or fibrosis affected $50-60 \%$ of the cortical tissue (fig. 1). The arterioles displayed mild to moderate hyalinosis (fig. 2c), while the interlobular arteries showed mild to moderate fibroelastic intimal thickening (fig. 2d). Immunofluorescence microscopy demonstrated granular deposits of IgG and C3 along the GBM. Analysis of IgG subclasses revealed dominant staining 


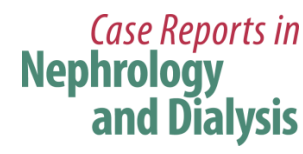

\begin{tabular}{l|l}
\hline Case Rep Nephrol Dial 2016;6:76-82 \\
\hline DOI: 10.1159/000446019 & $\begin{array}{l}\text { (c) 2016 The Author(s). Published by S. Karger AG, Basel } \\
\text { www.karger.com/cnd }\end{array}$ \\
\hline
\end{tabular}

Kubota et al:: Phospholipase A2 Receptor-Positive Idiopathic Membranous Glomerulonephritis with Onset at 95 Years: Case Report

for IgG4 (IgG4 > IgG1 > IgG3 > IgG2; fig. 3), while staining for IgA and IgM was very weak. The anti-PLA2R binding in the biopsy was positive. Congo red staining was negative. Electron microscopy showed subepithelial electron-dense deposits (EDD) in the GBM, but these subepithelial EDD were not associated with spike-like protrusions arising from the basement membrane (fig. 4). Stage 1 MGN was diagnosed due to these findings.

\section{Clinical Course}

Anasarca was treated with diuretics (furosemide at $80 \mathrm{mg}$ daily) and dietary restriction ( $6 \mathrm{~g}$ of salt and $700 \mathrm{ml}$ of water daily), achieving weight loss from 56.4 to $51.0 \mathrm{~kg}$. Because the patient did not want steroid therapy due to adverse effects such as bone disease, cyclosporin microemulsion (Neoral at $50 \mathrm{mg}$ daily) was added, and the level at $2 \mathrm{~h}$ after administration was titrated in the range of $600-1,000 \mathrm{ng} / \mathrm{ml}$. However, proteinuria persisted, and renal function deteriorated rapidly. Hemodialysis was started when Cre was $6.0 \mathrm{mg} / \mathrm{dl}$ and urea nitrogen was $102 \mathrm{mg} / \mathrm{dl}$ because of exacerbation of pleural effusion and generalized edema along with an increase in weight to $58 \mathrm{~kg}$ at 2 months after diagnosis.

\section{Discussion}

In 2009, Beck et al. [2] identified the M-type PLA2R as the major target podocyte antigen in adult idiopathic MGN and showed that it was expressed by podocytes and colocalized with IgG4 in glomerular immune deposits of patients with idiopathic MGN. A PLA2R band was detected in the serum of 26 patients (mean age $48.1 \pm 14.9$ years; range 21-88) of 37 patients (70\%) with idiopathic MGN, while it was not found in 8 patients with secondary MGN, 22 patients with other diseases, and 30 healthy controls. Qin et al. [4] evaluated Chinese MGN patients with the method of Beck et al. [2], and they detected anti-PLA2R autoantibodies in the serum of 49 patients (mean age $49.2 \pm 14.9$ years; range 18-77) of 60 patients (82\%) with idiopathic MGN, in 1 of 20 patients with lupus-associated MGN, in 1 of 16 patients with hepatitis B-associated MGN, and in 3 of 10 patients with tumor-associated MGN.

Akiyama et al. [3] investigated circulating anti-PLA2R antibodies in Japanese MGN patients using a highly sensitive Western blotting method under nonreducing conditions with human glomerular extract (at dilutions of 1:25, 1:10, and 1) as the primary antibody. AntiPLA2R antibodies were detected in 53 of 100 patients (aged $67 \pm 9$ years at diagnosis) with idiopathic MGN compared to 0 of 31 patients (aged $61 \pm 12$ years) with secondary MGN.

Zent et al. [5] studied 309 patients with idiopathic MGN and reported that 74 were elderly ( $\geq 60$ years old), with the oldest subject being 83 years old. The incidence of chronic renal insufficiency was significantly higher in elderly patients than in younger patients $(<60$ years old). Only 33 of 74 elderly patients (46\%) received treatment, which was steroids alone in $76 \%$, immunosuppressants alone in $9 \%$, or a combination in $16 \%$ of patients. The authors found no benefit of treatment in terms of the complete remission rate and the incidence of chronic renal insufficiency, so they suggested that steroid therapy should not be routinely offered to these elderly patients. O'Callaghan et al. [6] compared the clinical features and outcomes of MGN between 95 younger patients and 60 older patients aged $>60$ years, including 2 patients aged 80 and 85 years. There was a higher incidence of an identifiable cause for the nephropathy among the older patients, who were also more likely to have hypertension and more severe renal impairment than the younger patients. Abrass [7] reported on the treatment of elderly patients with MGN, stating that the only consistent recommendation is to avoid high-dose corticosteroids. She also mentioned that drug dosages 


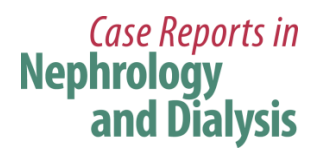

\begin{tabular}{l|l}
\hline Case Rep Nephrol Dial 2016;6:76-82 \\
\hline DOI: 10.1159/000446019 & $\begin{array}{l}\text { ○ 2016 The Author(s). Published by S. Karger AG, Basel } \\
\text { www.karger.com/cnd }\end{array}$ \\
\hline
\end{tabular}

Kubota et al.: Phospholipase A2 Receptor-Positive Idiopathic Membranous Glomerulonephritis with Onset at 95 Years: Case Report

should be modified and monitored carefully and that elderly patients may be particularly prone to the side effects and infectious complications of immunosuppressants.

When we investigated positivity for anti-PLA2R antibodies at the diagnosis of idiopathic MGN among patients attending our hospital, we identified 7 patients aged $75.1 \pm 10.2$ years (range 65-95) including the present case. Our patient was older than those reported by previous authors, such as Beck et al. [2] (48.1 \pm 14.9 years; range 21-88), Akiyama et al. [3] (67 \pm 9 years), and Qin et al. [4] (49.2 \pm 14.9 years; range 18-77). If nephrologists performed renal biopsy more frequently in elderly patients over 90 years of age with nephrotic range proteinuria, other such cases might be discovered.

In conclusion, we encountered a 95-year-old Japanese woman with nephrotic-range proteinuria, and renal biopsy revealed stage 1 MGN with IgG4 dominance. This patient did not have any underlying disease that could have caused secondary MGN, and anti-PLA2R antibody was positive, so idiopathic MGN was diagnosed. Corticosteroid therapy was avoided, but hemodialysis was required for generalized edema, and the patient is currently doing well on hemodialysis. This case reminds us that idiopathic MGN with anti-PLA2R antibodies can occur even at the very advanced age of 95 years.

\section{Acknowledgment}

This study was funded by the Okinaka Memorial Institute for Medical Research.

\section{Statement of Ethics}

The present report adhered to the Declaration of Helsinki and these patients have given their consent for the case report to be published.

\section{Disclosure Statement}

All authors report no conflicts of interest.

\section{References}

1 Hofstra JM, Wetzels JF: Management of patients with membranous nephropathy. Nephrol Dial Transplant 2012;27:6-9.

2 Beck LH Jr, Bonegio RG, Lambeau G, Beck DM, Powell DW, Cummins TD, Klein JB, Salant DJ: M-type phospholipase A2 receptor as target antigen in idiopathic membranous nephropathy. $\mathrm{N} \mathrm{Engl} \mathrm{J} \mathrm{Med}$ 2009;361:11-21.

-3 Akiyama S, Akiyama M, Imai E, Ozaki T, Matsuo S, Maruyama S: Prevalence of anti-phospholipase A2 receptor antibodies in Japanese patients with membranous nephropathy. Clin Exp Nephrol 2015;19:653660.

4 Qin W, Beck LH Jr, Zeng C, Chen Z, Li S, Zuo K, Salant DJ, Liu Z: Anti-phospholipase A2 receptor antibody in membranous nephropathy. J Am Soc Nephrol 2011;22:1137-1143.

5 Zent R, Nagai R, Cattran DC: Idiopathic membranous nephropathy in the elderly: a comparative study. Am J Kidney Dis 1997;29:200-206.

6 O'Callaghan CA, Hicks J, Doll H, Sacks SH, Cameron JS: Characteristics and outcome of membranous nephropathy in older patients. Int Urol Nephrol 2002;33:157-165.

7 Abrass C: Treatment of membranous nephropathy in the elderly. Semin Nephrol 2003;23:373-378. 


\section{Case Reports in \\ Nephrology and Dialysis}

\begin{tabular}{l|l}
\hline Case Rep Nephrol Dial 2016;6:76-82 \\
\hline DOI: 10.1159/000446019 & $\begin{array}{l}\text { ○ 2016 The Author(s). Published by S. Karger AG, Basel } \\
\text { www.karger.com/cnd }\end{array}$ \\
\hline
\end{tabular}

Kubota et al.: Phospholipase A2 Receptor-Positive Idiopathic Membranous Glomerulonephritis with Onset at 95 Years: Case Report

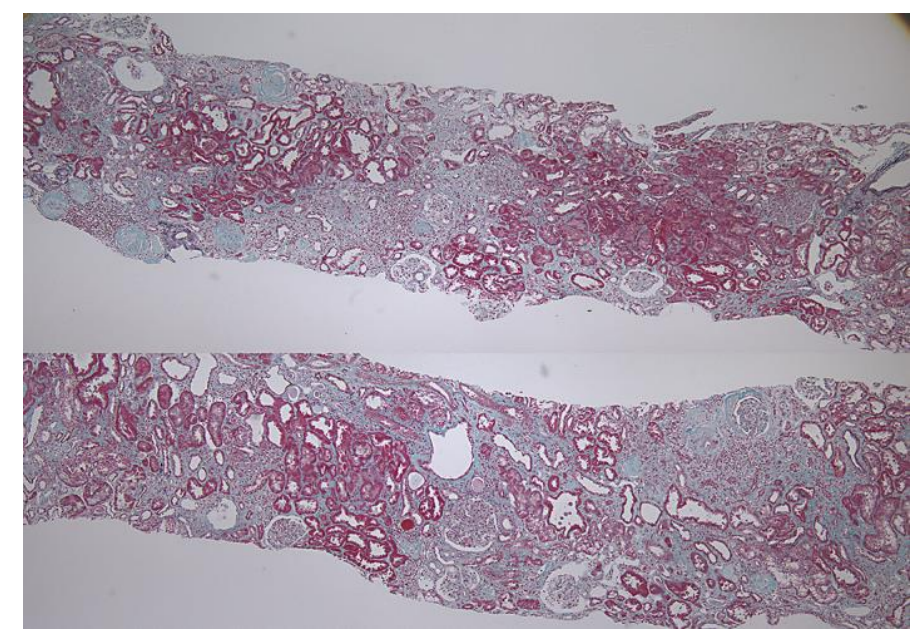

Fig. 1. Light microscopy of a renal biopsy specimen containing 36 glomeruli revealed global sclerosis in 22. In the tubulointerstitial region, 50-60\% of the cortical tissue showed atrophy or fibrosis (Masson's trichrome stain).
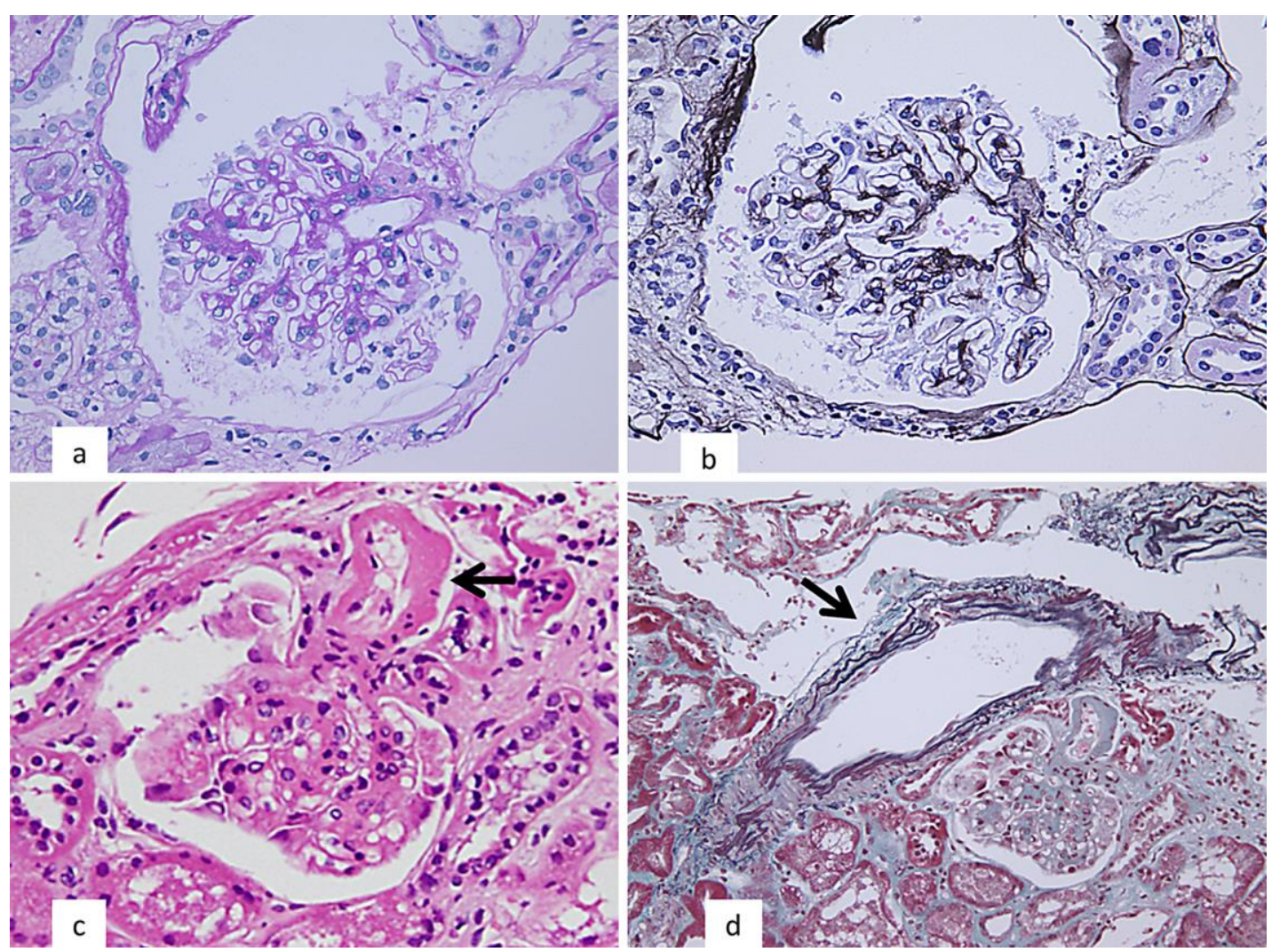

Fig. 2. a The other 13 glomeruli showed mild expansion of the mesangial matrix (periodic acid-Schiff stain). b There was no definite spike formation, bubbling, or thickening of the GBM (periodic acidmethenamine silver stain). $\mathbf{c}$ There was mild hyalinosis of the arterioles (arrow) (HE stain). $\mathbf{d}$ Interlobular arteries showed mild fibroelastic intimal thickening (arrow) (Masson's trichrome stain). 
Case Reports in

Nephrology

and Dialysis
Case Rep Nephrol Dial 2016;6:76-82

\begin{tabular}{l|l}
\hline DOI: $10.1159 / 000446019$ & C 2016 The Author(s). Published by S. Karger AG, Basel
\end{tabular} www.karger.com/cnd

Kubota et al.: Phospholipase A2 Receptor-Positive Idiopathic Membranous Glomerulonephritis with Onset at 95 Years: Case Report

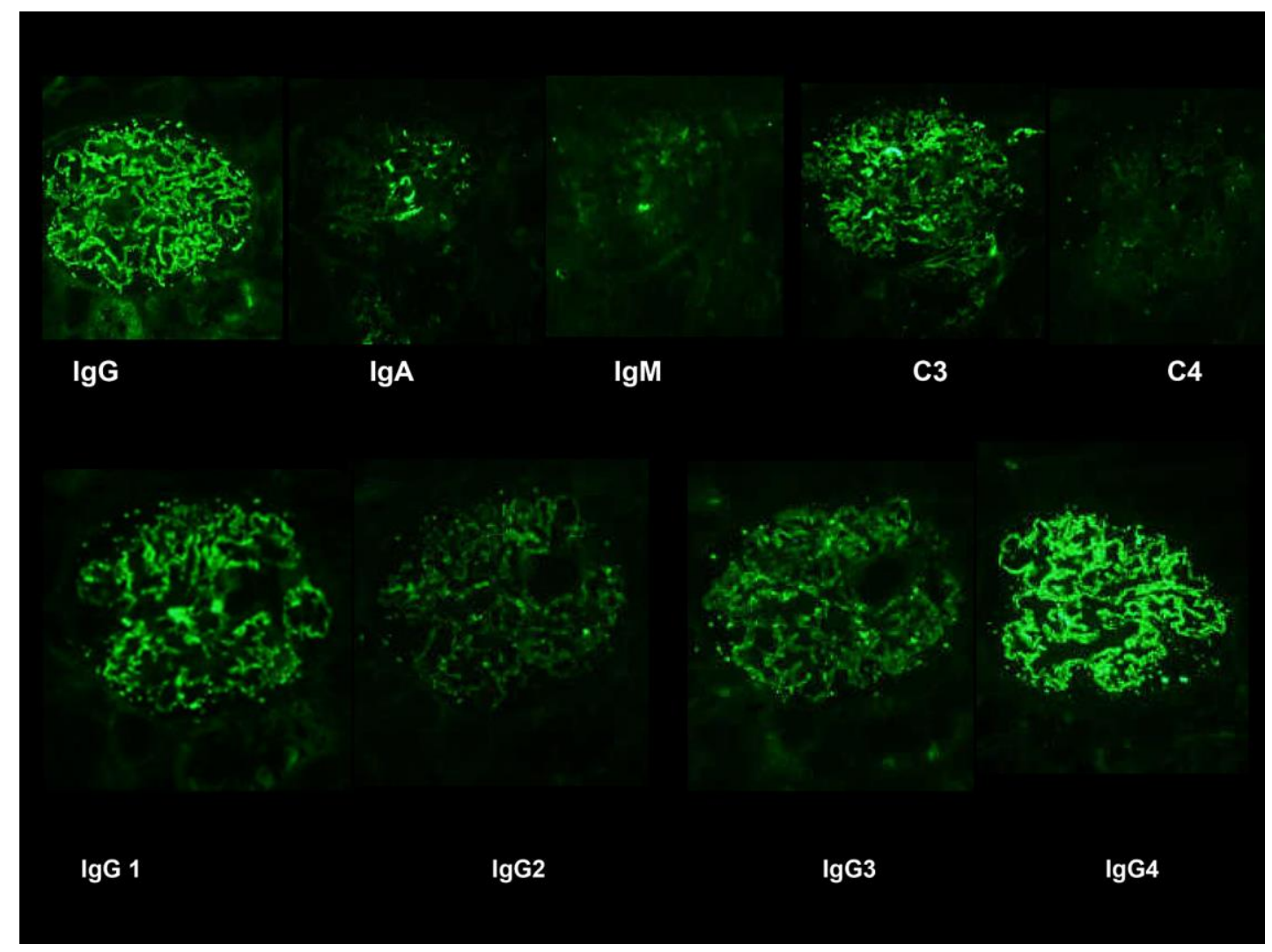

Fig. 3. Immunofluorescence microscopy demonstrated granular deposits of IgG and C3 along the GBM. Analysis of IgG subclasses revealed dominance of IgG4 (IgG4 > IgG1 > IgG3 > IgG2). 


\section{Case Reports in \\ Nephrology and Dialysis}

\begin{tabular}{l|l}
\hline Case Rep Nephrol Dial 2016;6:76-82 \\
\hline DOI: 10.1159/000446019 & $\begin{array}{l}\text { c } 2016 \text { The Author(s). Published by S. Karger AG, Basel } \\
\text { www.karger.com/cnd }\end{array}$ \\
\hline
\end{tabular}

Kubota et al.: Phospholipase A2 Receptor-Positive Idiopathic Membranous Glomerulonephritis with Onset at 95 Years: Case Report

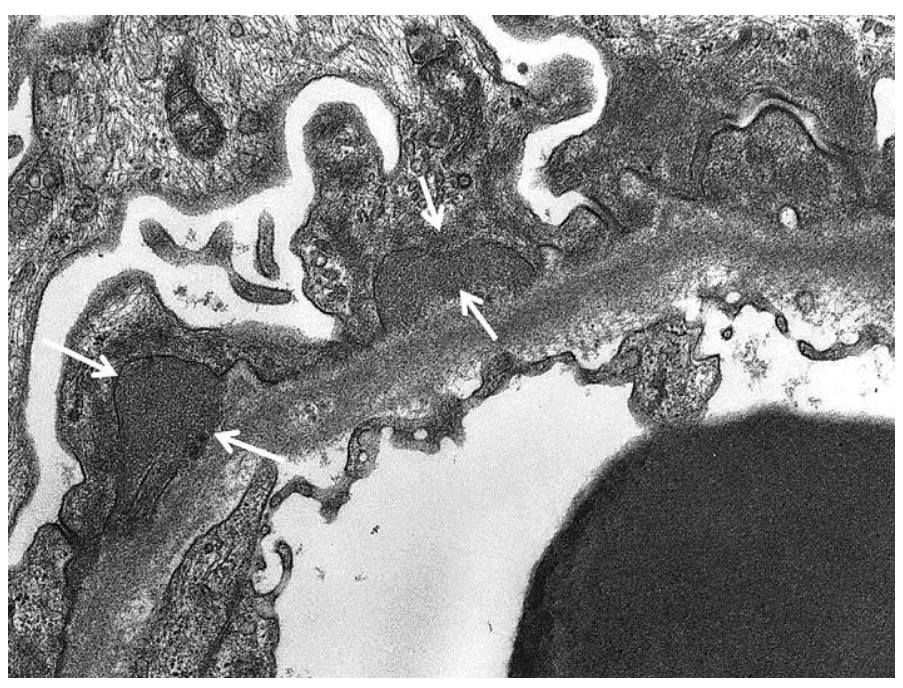

Fig. 4. Electron microscopy showed subepithelial EDD (arrows) in the GBM. These subepithelial EDD lacked spike-like protrusions from the basement membrane. 